\title{
Influence of Cotton Root System Size on Tolerance to Rotylenchulus reniformis
}

\author{
Rafael Galbieri, Programa de Pós-Graduação em Agricultura Tropical, Universidade Federal de Mato Grosso, Cuiabá, MT, Brazil; Richard \\ F. Davis, ${ }^{\dagger}$ USDA Agricultural Research Service, Crop Protection and Management Research Unit, P.O. Box 748, Tifton, GA 31793; \\ Leimi Kobayasti and Maria C. F. Albuquerque, Universidade Federal de Mato Grosso - UFMT, Cuiabá - MT, Brazil; and Jean-Louis Bélot, \\ Fabio R. Echer, and Alberto S. Boldt, Instituto Mato-grossense do Algodão - IMAmt, Primavera do Leste - MT, Brazil
}

\begin{abstract}
The factors that influence the ability of cotton to minimize yield loss despite parasitism by Rotylenchulus reniformis (i.e., tolerance) were evaluated for 12 cotton genotypes. Reproduction of $R$. reniformis and total length of the root system were measured under greenhouse conditions, and the relationship of those variables to yield loss caused by $R$. reniformis in infested fields was evaluated. Values for nematodes per gram of root and root length were standardized by setting the genotype with greatest value as $100 \%$ and then calculating a percentage for each genotype. There was significant variability among genotypes in yield loss, resistance, and root length. Average yield loss for the genotypes ranged from $10.4 \%$ for IAC 26RMD to $43.2 \%$ for IMACD $5675 \mathrm{~B} 2 \mathrm{RF}$. The least nematode reproduction was on IAC 26RMD, which

had $49.6 \%$ of the reproduction on the susceptible check, Deltapine 16 . The genotype with the shortest total root length was $34 \%$ less than the genotype with the greatest length. There was a significant linear relationship between percentage yield loss caused by $R$. reniformis and root length and nematodes per gram of root, both expressed as a percentage of the maximum, represented by the following equation: Yield loss $(\%)=16.1258-0.1918^{*}$ (\% maximum root length $)+0.3728 *(\%$ maximum eggs + vermiform $/ g$ of roots). We conclude that tolerance to $R$. reniformis in cotton is influenced by the size of the root system and the parasitic load on the plant (nematodes per gram of root). Management approaches that increase root growth may lower the parasitic load, thereby reducing losses in cotton to $R$. reniformis.
\end{abstract}

Cotton is produced on 30 million hectares in more than 70 countries with a total production of fiber in the 2015/16 cropping season of 21 million MT (USDA-FAS 2017). Countries with the greatest production are India, China, the United States, Pakistan, and Brazil (USDA-FAS 2017). Plant-parasitic nematodes cause significant crop losses in cotton (Starr et al. 2007), and Rotylenchulus reniformis Linford \& Oliveira, the reniform nematode, is widespread throughout tropical and subtropical regions (Robinson et al. 1997) and is one of the primary nematode pathogens of cotton (Robinson 2007). The annual yield loss attributable to this nematode in the United States is approximately $2 \%$ of total cotton produced (Weaver 2015), but losses in some states can be 4-5\% (Lawrence et al. 2017). In Brazil, 63\% of the country's cotton production area is in the state of Mato Grosso, and $R$. reniformis infests approximately $15 \%$ of the area, reaching almost $40 \%$ in the southern region of the state (CONAB 2017; Galbieri et al. 2016). During the last 15 years in both countries, there has been an increase in the incidence and damage caused by $R$. reniformis in cotton (Galbieri et al. 2016; Robinson 2007; Weaver 2015). Although $R$. reniformis can be found in a range of soil textures, it reproduces best in finer textured soils, especially soil with a relatively high silt content (Asmus and Ishimi 2009; Robinson et al. 2005).

The most efficient tactic for nematode control is the use of hostplant resistance (Robinson 2007), which results in the plant suppressing nematode reproduction (Cook and Evans 1987). As of 2017, no cotton cultivars with resistance to $R$. reniformis were available. Nematode tolerance is defined as the plant's ability to sustain minimal yield loss despite nematode parasitism in infested fields (Cook and Evans 1987). Although tolerance does not decrease nematode population levels, it improves productivity in nematode-infested fields (Blessitt et al. 2012). The most effective genotypes for reducing losses to nematodes would express both resistance and tolerance (Robinson

${ }^{\dagger}$ Corresponding author: R. F. Davis; E-mail: Richard.Davis@ars.usda.gov

Funding: The present research was conducted under the financial support of Instituto Mato-grossense do Algodão, MT, Brazil (project Propeq no. 459/ 2015).

Accepted for publication 27 May 2018.

This article is in the public domain and not copyrightable. It may be freely reprinted with customary crediting of the source. The American Phytopathological Society, 2018.
2007). Although nematode resistance has been extensively studied, nematode tolerance has received limited attention (Davis and Stetina 2016; Trudgill 1991).

A plant's root system is crucial to its ability to grow and produce a crop, and genotypes with more expansive root systems are better able to exploit resources in the soil and can tolerate greater abiotic and biotic stress (Iqbal et al. 2010; Mills et al. 2012; Paez-Garcia et al. 2015). Morphological characteristics of the cotton root system show genetic variability (McMichael and Quisenberry 1991; Quisenberry and McMichael 1996), and root length is related to drought tolerance for this crop (Iqbal et al. 2010; Zafar and Azhar 2015). Structures such as rhizotrons and minirhizotrons may be used to collect root system data (James et al. 1985; Judd et al. 2015). Root length ranges in length from a few centimeters in seedlings to hundreds of meters in older plants that have experienced ideal growth conditions (Judd et al. 2015; Nayakekorala and Taylor 1990; Oosterhuis and Zhao 1994; Thompson et al. 2012). Modern techniques simplify capturing two-dimensional images of root systems and utilizing software programs to quantify and analyze them (Himmelbauer et al. 2004; Paez-Garcia et al. 2015). Although the mechanisms of tolerance to nematodes in cotton are unknown, hypotheses have included attributes of the root system such as size and vigor as possible contributors (Davis and Stetina 2016). The variable nematodes per gram of root is a measure of the parasitic load on a plant and may have a significant role in a plant's tolerance to nematodes (Davis et al. 2003; Schrimsher et al. 2014). Nematodes per gram of root is also reported as a measure of the effect of resistance on nematode population levels (McCarty et al. 2012, 2017; Wubben et al. 2017). The size of a plant's root system may influence the number of nematodes per gram of root.

Identifying factors that influence the ability of cotton plants to exhibit tolerance to parasitism by $R$. reniformis can provide direction for future research and provide immediate utility for nematode management in the field. Thus, the objectives of this study were to determine 1) whether cotton genotypes differ in the degree of yield loss caused by $R$. reniformis, and 2) whether the size of a plant's root system or its relative host status for $R$. reniformis affects the degree of yield losses caused by $R$. reniformis.

\section{Materials and Methods}

Nematode reproduction trials. The ability of $R$. reniformis to reproduce on 12 cotton genotypes ( 10 cultivars and 2 germplasm lines) plus one susceptible check (Deltapine 16) was evaluated in three tri-

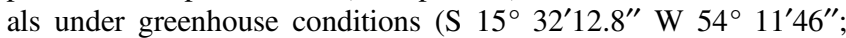


ambient temperature in the greenhouse $=27 \pm 2^{\circ} \mathrm{C}$ ). The 10 cultivars used account for more than $70 \%$ of the area planted with cotton in the state of Mato Grosso in the years 2014 and 2015 (Galbieri et al. 2016). Each trial consisted of 10 replications in a randomized complete block design. Cotton seeds were planted in June 2015 for Trial 1, August for Trial 2, and October for Trial 3 in 15-cm-diameter pots containing 2.4 liters of potting substrate. Seedlings were thinned to one plant per pot before inoculation. The potting substrate used was a soil, sand, and manure mixture in a 2:1:1 ratio with the final physical composition consisting of $29 \%$ clay, $5 \%$ silt, and $66 \%$ sand, and chemically with a $\mathrm{pH}$ of 6.1 and base saturation of $65 \%$. The substrate was autoclaved at $120^{\circ} \mathrm{C}$ for $12 \mathrm{~min} 15$ days prior to planting. Carbosulfan (1.2 g a.i./liter sprayed at approximately $20 \mathrm{ml} / \mathrm{m}^{2}$ ) was applied as needed to control aphids (Aphis gossypii).

Eggs of $R$. reniformis were extracted from 95-day-old Castor bean (Ricinus communis L.) for use as inoculum by shaking the roots in a $0.25 \%$ sodium hypochlorite solution for 2 min (Walters and Barker 1993) approximately $1 \mathrm{~h}$ prior to inoculation. Nine days after planting, 8,000 eggs of $R$. reniformis in $7 \mathrm{ml}$ of water were added to each pot (approximately 665 eggs per $200 \mathrm{~cm}^{3}$ of soil) by distributing the inoculum equally into two holes approximately $1.5 \mathrm{~cm}$ equidistant from the stem and $2.5 \mathrm{~cm}$ deep and then filling the holes with the substrate.

One hundred days after inoculation, intact root systems were carefully washed, weighed, and immersed in $0.20 \%$ trypan blue solution for 3 min to stain egg masses (Sharma and Ashokkumar 1991), which were then counted. Eggs were then extracted from roots by the sucrose solution centrifugation method (Coolen and D'Herde 1972). Eggs and vermiform nematodes were counted and subjected to square-root transformation to normalize the error variances before statistical analysis, although nontransformed data are presented. Data from the three trials were pooled for analysis with mean separation by Fisher's protected least significant difference $\left(\mathrm{LSD}_{0.05}\right)$.

Rhizotron root trials. The morphological characteristics of the root systems of the 12 cotton genotypes were recorded in two experiments in randomized complete block designs with six replications carried out under greenhouse conditions (temperature $=28 \pm 2{ }^{\circ} \mathrm{C}$ ). Each plot consisted of rhizotrons with the following dimensions: $60 \mathrm{~cm}$ wide, $120 \mathrm{~cm}$ long, and $2 \mathrm{~cm}$ thick. The rhizotron was made of glass $(0.4 \mathrm{~cm}$ thick) and was enclosed on all sides except the top, and rhizotrons were held at a vertical angle of $60^{\circ}$ to promote root growth next to the glass (Fig. 1). Rhizotrons were covered externally with opaque plastic to prevent light from affecting root growth. The substrate used was Basaplant commercial substrate, sand, and manure mixture (1:0.62:0.072 ratio) with $0.72 \mathrm{~g}$ of potassium chloride (KCL) and $1.72 \mathrm{~g}$ of monoammonium phosphate (MAP) added per $\mathrm{kg}$ of substrate. The final composition of the blend was $80 \%$ sand, $3 \%$ silt, and $17 \%$ clay with $\mathrm{pH}=6.1$ and $57 \%$ base saturation. Seeds of each cotton genotype were germinated in paper rolls for $60 \mathrm{~h}$ in a
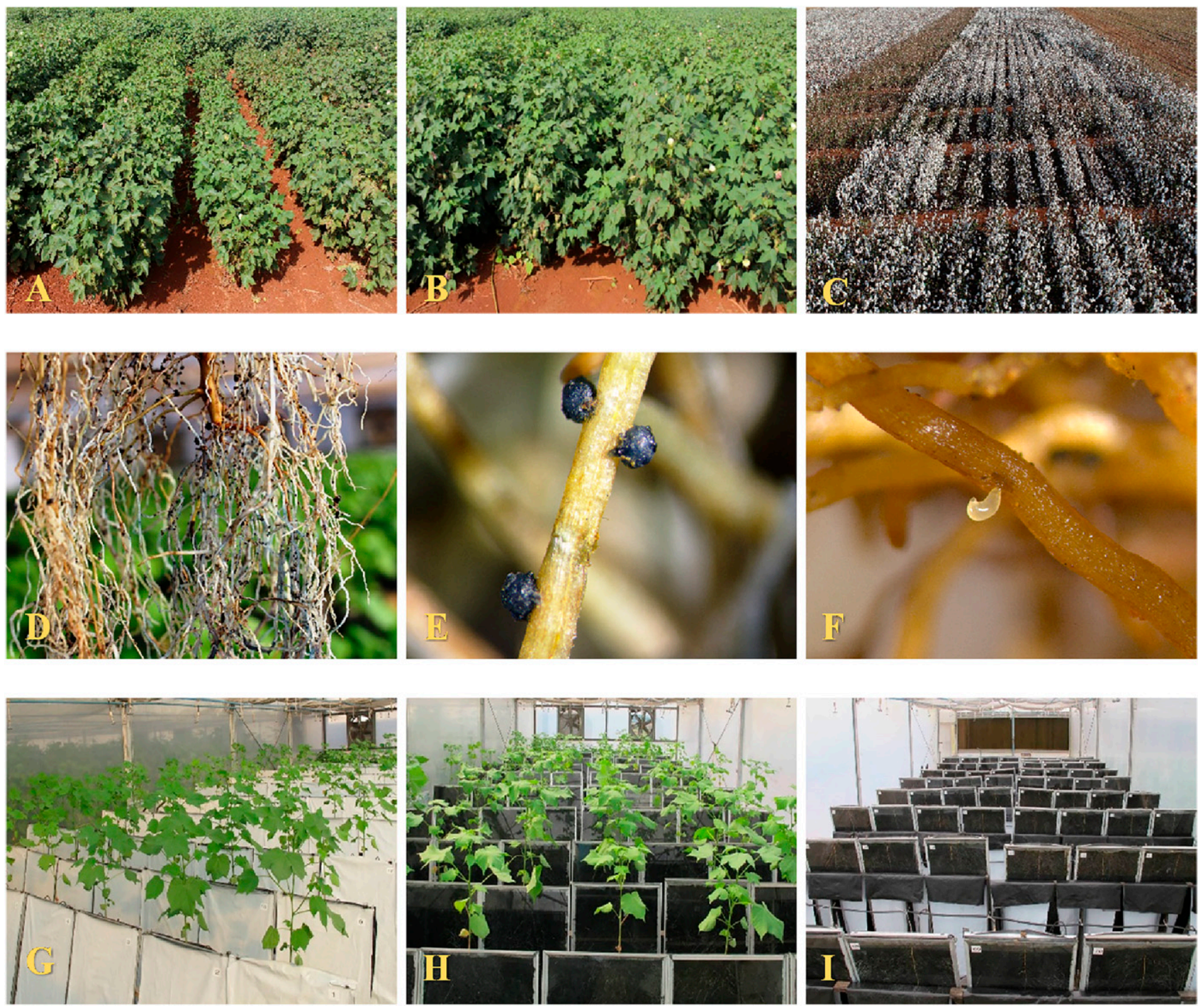

Fig. 1. A, An intolerant genotype parasitized by Rotylenchulus reniformis; B, a tolerant genotype parasitized by $R$. reniformis; C, a tolerance field trial ready for harvest; D, egg masses of $R$. reniformis on roots stained with trypan blue; $\mathrm{E}$, egg masses of $R$. reniformis on a root; $\mathrm{F}$, female $R$. reniformis on a root; $\mathbf{G}$, rhizotrons covered with plastic; $\mathrm{H}$, rhizotrons with plastic removed; and I, back side of rhizotrons showing supporting structures and automatic irrigation lines. 
growth chamber at $25^{\circ} \mathrm{C}$, then uniformly sized seedlings of each genotype were selected and planted into the rhizotrons (one plant per rhizotron) at a depth of $2 \mathrm{~cm}$. Hoagland nutrient solution (Hoagland and Arnon 1950) (150 ml per rhizotron) was added to each rhizotron each week, and thiamethoxam ( $0.3 \mathrm{~g}$ a.i./liter sprayed at approximately $20 \mathrm{ml} / \mathrm{m}^{2}$ ) was used as needed to control aphids (Aphis gossypii) and thrips (Frankliniella schultzei). Automated drip irrigation approximated ideal growing conditions.

Forty-five days after transplanting, rhizotrons were opened, and each root system was carefully washed with running water over a sieve so that small pieces of root that broke off could be recovered. The lengths of taproots were measured, and the root systems were stored in 500-ml plastic bottles in a 55\% hydrated ethyl alcohol solution at $10^{\circ} \mathrm{C}$. Roots from each rhizotron were chopped into pieces approximately $1.5 \mathrm{~cm}$ in length, rinsed to remove excess alcohol, and placed in a $30 \times 40 \times 2 \mathrm{~cm}$ acrylic tray with $700 \mathrm{ml}$ of water. The tray was scanned by an Epson Expression 10.000 XL model scanner, and a digital image was saved. Length, diameter, and root surface data for each root system were obtained using the WinRHIZO software program (Regent Instruments Canada Inc.). Roots were dried at $65^{\circ} \mathrm{C}$ for $72 \mathrm{~h}$, and the dry weight of the samples was determined. Morphological data and weight of the root systems were subjected to analysis of

Table 1. Rotylenchulus reniformis levels on cotton genotypes in greenhouse studies 100 days after inoculation with 8,000 eggs per pot

\begin{tabular}{lccc}
\hline Genotype & $\begin{array}{c}\text { Vermiform }+ \\
\text { eggs/pot }^{\mathbf{z}}\end{array}$ & $\begin{array}{c}\text { Vermiform + eggs/g } \\
\text { root }\end{array}$ & $\begin{array}{c}\text { Egg masses/g } \\
\text { root }\end{array}$ \\
\hline BRS 371RF & $102,430 \mathrm{a}$ & $4,096 \mathrm{def}$ & $39.1 \mathrm{e}$ \\
BRS 372 & $107,244 \mathrm{a}$ & $4,119 \mathrm{cde}$ & $40.1 \mathrm{de}$ \\
DP & $66,452 \mathrm{~cd}$ & $2,911 \mathrm{fg}$ & $35.0 \mathrm{e}$ \\
555BGRR & & & \\
FM 966LL & $108,309 \mathrm{a}$ & $6,271 \mathrm{ab}$ & $71.7 \mathrm{ab}$ \\
FM 975WS & $93,035 \mathrm{ab}$ & $3,743 \mathrm{efg}$ & $37.8 \mathrm{e}$ \\
IAC 26RMD & $50,475 \mathrm{~d}$ & $2,841 \mathrm{~g}$ & $34.4 \mathrm{e}$ \\
IMA 2027 & $82,971 \mathrm{abc}$ & $3,344 \mathrm{efg}$ & $35.2 \mathrm{e}$ \\
IMA & $94,741 \mathrm{ab}$ & $5,276 \mathrm{bc}$ & $55.6 \mathrm{bc}$ \\
5675B2RF & & & \\
IMA 8276 & $73,363 \mathrm{bc}$ & $2,987 \mathrm{fg}$ & $35.7 \mathrm{e}$ \\
TMG 42WS & $98,704 \mathrm{a}$ & $4,889 \mathrm{bcd}$ & $57.3 \mathrm{bc}$ \\
TMG 81WS & $92,268 \mathrm{ab}$ & $3,851 \mathrm{def}$ & $34.4 \mathrm{e}$ \\
TMG 82WS & $73,927 \mathrm{bc}$ & $3,297 \mathrm{efg}$ & $31.8 \mathrm{e}$ \\
Deltapine 16 & $101,739 \mathrm{a}$ & $7,243 \mathrm{a}$ & $94.5 \mathrm{a}$ \\
Mean & 88,128 & 4,221 & 46.4 \\
\hline
\end{tabular}

${ }^{\mathrm{z}}$ Nontransformed data are presented; however, statistical analyses were performed on square-root transformed data. Results are the pooled analysis of three trials. Values in the same column followed by the same letter are not significantly different according to Fisher's protected $\operatorname{LSD}_{(0.05)}$.

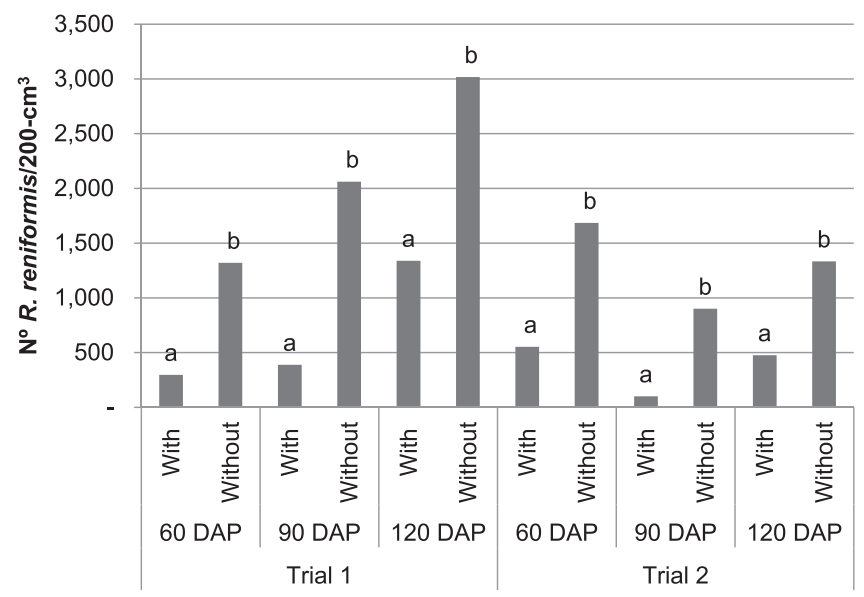

Fig. 2. Rotylenchulus reniformis population levels averaged across 12 genotypes at three sampling dates in two trials from plots either treated or not treated with nematicide. Nontransformed means are shown, but statistical analysis used squareroot transformed data. Bars within a trial and sampling date followed by the same letter are not significantly different according to Fisher's protected $\mathrm{LSD}_{(0.05)}$. variance with mean separation by Fisher's protected least significant difference $\left(\mathrm{LSD}_{0.05}\right)$.

Tolerance trials in the field. Yield loss due to $R$. reniformis was measured for 12 cotton genotypes (the 10 cultivars and 2 germplasm lines evaluated for nematode reproduction) in 2015 in two different field experiments, each with six replications in a randomized splitplot design. The genotype DP 16 was not included because it is not well adapted to the test area. The main plot factor was cotton genotype and the subplot factor was nematicide treatment (treated or not treated with aldicarb at $0.9 \mathrm{~kg}$ a.i./ha in furrow at planting and 30 days after planting [DAP] as a side-dress application). Trial 1 was in the southern region and Trial 2 in the central zone of Mato Grosso in Brazil. All field trials were planted at $11 \mathrm{seed} / \mathrm{m}$. Trial 1 was planted 16 December 2014 (S 16 ${ }^{\circ} 56^{\prime} 35.2766^{\prime \prime}$ W 54 $4^{\circ} 02^{\prime}$ $03.29407^{\prime \prime}$ ) in soil that was $15.6 \%$ sand, $17.5 \%$ silt, and $66.9 \%$ clay, with $4.1 \%$ organic matter, $\mathrm{pH}=6.0$, and base saturation of $51.9 \%$. Trial 2 was planted on 20 December 2014 (S 15 $25^{\prime} 59^{\prime \prime}$ W 54 $57^{\prime}$ $\left.59^{\prime \prime}\right)$ in soil that was $23.4 \%$ sand, $5.4 \%$ silt, and $71.2 \%$ clay, with $3.3 \%$ organic matter, $\mathrm{pH}=5.9$, and base saturation $50 \%$. Both fields were naturally infested with $R$. reniformis and had been planted with cotton each year for approximately 20 years prior to study initiation. Fields were not irrigated. Millet (Pennisetum glaucum) was grown as a cover crop between cotton crops in both fields. Twenty days before planting cotton, the millet was killed with glyphosate 3 liters ${ }^{\cdot} \mathrm{ha}^{-1}$. Cotton was planted with $0.90 \mathrm{~m}$ between rows into the millet straw with a no-till planter. Subplots consisted of two 7-m-long rows. Cotton seeds were treated with insecticide (thiamethoxam $2.1 \mathrm{~g}$ a.i. $/ \mathrm{kg}$ of seed) and fungicide (carboxin $1.2 \mathrm{~g}$ a.i./ $\mathrm{kg}$ of seed and thiram $1.2 \mathrm{~g}$ a. i./kg of seed). All plots were identically managed with fertilizers, insecticides, fungicides, and herbicides according to typical management recommendations used in southern Mato Grosso.

Yield data were collected at harvest on 23 July 2015 for Trial 1 and 30 July 2015 for Trial 2. Fifteen days prior to harvest, plants were treated with a defoliant (thidiazuron + diuron) and a boll opener (ethephon + cyclanilide). Seed cotton (fiber plus seeds) from each plot was mechanically harvested and weighed; the percentage lint (fiber only) was determined by ginning 30 bolls from each plot, and the percentage lint in the subsample was used to calculate a lint yield for the plot. Yield loss caused by $R$. reniformis was calculated for each plot as the difference in yield between the plots treated and not treated with nematicide divided by the yield of the nematicide-treated plot. Data on percentage yield loss were analyzed as a randomized complete block design.

Soil samples to quantify nematode population levels were collected 60, 90, and 120 DAP and consisted of a composite of 8 cores per plot ( $3 \mathrm{~cm}$ diameter and approximately $25 \mathrm{~cm}$ deep) collected from the root zone. Nematodes were extracted from $200 \mathrm{~cm}^{3}$ soil by centrifugal flotation (Jenkins 1964). The number of $R$. reniformis in each sample was subjected to square-root transformation. Nematode

Table 2. Total root system length of cotton genotypes 45 days after planting in rhizotrons under greenhouse conditions

\begin{tabular}{lc}
\hline Genotype & Root length/plant $(\mathbf{c m})^{\mathbf{z}}$ \\
\hline BRS 371RF & $8,707 \mathrm{bcd}$ \\
BRS 372 & $9,733 \mathrm{abc}$ \\
DP 555BGRR & $10,524 \mathrm{ab}$ \\
FM 966LL & $9,197 \mathrm{abc}$ \\
FM 975WS & $9,899 \mathrm{abc}$ \\
IAC 26RMD & $9,439 \mathrm{abc}$ \\
IMA 2027 & $10,923 \mathrm{a}$ \\
IMA 5675B2RF & $6,933 \mathrm{~d}$ \\
IMA 8276 & $10,015 \mathrm{abc}$ \\
TMG 42WS & $8,481 \mathrm{~cd}$ \\
TMG 81WS & $9,374 \mathrm{abc}$ \\
TMG 82WS & $8,459 \mathrm{~cd}$ \\
\hline
\end{tabular}

${ }^{\mathrm{z}}$ Means followed by the same letter are not significantly different according to Fisher's protected $\operatorname{LSD}_{(0.05)}$. Results are the pooled analysis of two trials. 
counts and yield data were subjected to analysis of variance with mean separation by Fisher's protected least significant difference $\left(\mathrm{LSD}_{0.05}\right)$. Data from the trials were pooled for analysis to determine if the results for the genotypes were consistent in all trials (no significant genotype $\times$ trial interactions).

Regression analyses. The effects of host-plant resistance and root system size on yield loss caused by $R$. reniformis were evaluated through regression analysis. The relationships between root length and cotton yield with and without nematicide also were evaluated. The data in these analyses were the means of each of the 12 genotypes of cotton from the two field trials for yield loss, three greenhouse trials for nematode reproduction, and two rhizotron trials measuring root length. For each variable, the genotype with the greatest mean was assigned to be $100 \%$, and the other genotypes were calculated as a percentage of that maximum. Multiple regression analysis was used to evaluate the combined effects of nematodes per gram of roots and roots length on yield loss. All statistical analyses for this study were performed using the "stats" package of the R statistical system (version 3.3.3; R Development Core Team 2014).

\section{Results}

Nematode reproduction trials. The genotypes performed consistently in the trials measuring the reproduction of $R$. reniformis (no genotype $\times$ trial interaction for nematodes/pot $[P=0.5449]$, nematodes/ $\mathrm{g} \operatorname{root}[P=0.6643]$, or egg masses/g root $[P=0.3924])$, so a pooled analysis of the data from the three trials was appropriate. The genotypes differed in the number of eggs + vermiform nematodes per pot, the number of eggs + vermiform nematodes per gram of root, and the number of egg masses per gram of root (Table 1). Nine genotypes had fewer nematodes per pot than the susceptible check (Deltapine 16). Not including the susceptible check, the genotype with the lowest value (IAC 26RMD) had 53\% fewer nematodes per pot than the genotype with the highest value (FM 966LL). Eleven genotypes had fewer nematodes per gram of root and egg masses per gram of root. Not including the susceptible check, the genotype with the lowest nematodes per gram of root value (IAC 26RMD) was 55\% lower than the genotype with the highest value (FM 966LL). The genotype with the lowest egg masses per gram of root value (TMG 82WS) was $56 \%$ lower than the genotype with the highest value (FM 966LL)

Rhizotron root trials. Root length measured for the genotypes was consistent between the two rhizotron trials (no genotype $\times$ trial interaction; $P=0.7138$ ), so a pooled analysis of the data was appropriate. In the pooled analysis, total root length differed among the 12 genotypes (Table 2). The genotype with the shortest total root length was $34 \%$ shorter than the genotype with the longest root length.

Tolerance trials in the field. Individual plots were not sampled at 0 DAP; however, composite samples taken across the study areas at 0 DAP found $890 R$. reniformis $/ 200 \mathrm{~cm}^{3}$ for Trial 1 and $720 R$. reniformis $/ 200 \mathrm{~cm}^{3}$ for Trial 2 . On all sampling dates in both trials, plots receiving the nematicidal applications had fewer nematodes than

Table 3. Yield of cotton genotypes with and without nematicide application and percent yield loss caused by Rotylenchulus reniformis in 2015 (Trial 1)

\begin{tabular}{lccc}
\hline Genotype & Yield with nematicide (kg lint/ha) $)^{\mathbf{x}, \mathbf{y}}$ & Yield without nematicide (kg lint/ha) & Yield loss $(\%)^{\mathbf{z}}$ \\
\hline BRS 371RF & $1,467 \mathrm{de} \mathrm{A}$ & $1,205 \mathrm{de} \mathrm{B}$ & $16.6 \mathrm{cde}$ \\
BRS 372 & $1,543 \mathrm{~cd} \mathrm{~A}$ & $1,281 \mathrm{de} \mathrm{B}$ & $17.0 \mathrm{cde}$ \\
DP 555BGRR & $2,121 \mathrm{a} \mathrm{A}$ & $1,852 \mathrm{a} \mathrm{B}$ & $12.5 \mathrm{de}$ \\
FM 966LL & $1,253 \mathrm{e} \mathrm{A}$ & $864 \mathrm{fg} \mathrm{B}$ & $30.1 \mathrm{bcd}$ \\
FM 975WS & $1,971 \mathrm{ab} \mathrm{A}$ & $1,209 \mathrm{de} \mathrm{B}$ & $38.8 \mathrm{ab}$ \\
IAC 26RMD & $1,784 \mathrm{bc} \mathrm{A}$ & $1,581 \mathrm{bc} \mathrm{A}$ & $8.6 \mathrm{e}$ \\
IMA 2027 & $1,761 \mathrm{bc} \mathrm{A}$ & $1,372 \mathrm{~cd} \mathrm{~B}$ & $20.1 \mathrm{cde}$ \\
IMA 5675B2RF & $1,496 \mathrm{de} \mathrm{A}$ & $720 \mathrm{~g} \mathrm{~B}$ & $51.2 \mathrm{a}$ \\
IMA 8276 & $1,636 \mathrm{~cd} \mathrm{~A}$ & $1,260 \mathrm{de} \mathrm{B}$ & $21.4 \mathrm{bcde}$ \\
TMG 42WS & $1,718 \mathrm{~cd} \mathrm{~A}$ & $1,080 \mathrm{ef} \mathrm{B}$ & $34.4 \mathrm{abc}$ \\
TMG 81WS & $1,916 \mathrm{ab} \mathrm{A}$ & $1,602 \mathrm{abc} \mathrm{B}$ & $15.6 \mathrm{de}$ \\
TMG 82WS & $2,071 \mathrm{a} \mathrm{A}$ & $1,756 \mathrm{ab} \mathrm{B}$ & $14.6 \mathrm{de}$ \\
Mean & 1,728 & 1,315 & 23 \\
\hline
\end{tabular}

${ }^{x}$ Means within a column followed by the same lowercase letter are not significantly different according to Fisher's protected LSD $(0.05)$. Means within a row followed by the same uppercase letter (comparison of nematicide treated and nontreated plots of each genotype) are not significantly different according to Fisher's protected $\operatorname{LSD}_{(0.05)}$.

${ }^{y}$ Nematicide treatment was aldicarb at $0.9 \mathrm{~kg}$ a.i./ha in furrow at planting and a side-dress application 30 days after planting.

${ }^{\mathrm{z}}$ Percent yield loss was calculated as [(yield with nematicide/yield without nematicide)/yield with nematicide]*100.

Table 4. Yield of cotton genotypes with and without nematicide application and percent yield loss caused by Rotylenchulus reniformis in 2015 (Trial 2)

\begin{tabular}{lccc}
\hline Genotype & Yield with nematicide (kg lint/ha) $\mathbf{x , y}$ & Yield without nematicide (kg lint/ha) & Yield loss $(\%)^{\mathbf{z}}$ \\
\hline BRS 371RF & $1,644 \mathrm{de} \mathrm{A}$ & $1,263 \mathrm{~d} \mathrm{~B}$ & $21.9 \mathrm{abcd}$ \\
BRS 372 & $1,702 \mathrm{de} \mathrm{A}$ & $1,453 \mathrm{bcd} \mathrm{B}$ & $13.8 \mathrm{~d}$ \\
DP 555BGRR & $2,257 \mathrm{a} \mathrm{A}$ & $1,828 \mathrm{a} \mathrm{B}$ & $18.5 \mathrm{~cd}$ \\
FM 966LL & $1,308 \mathrm{f} \mathrm{A}$ & $840 \mathrm{e} \mathrm{B}$ & $34.1 \mathrm{ab}$ \\
FM 975WS & $2,031 \mathrm{bc} \mathrm{A}$ & $1,380 \mathrm{~cd} \mathrm{~B}$ & $30.6 \mathrm{abc}$ \\
IAC 26RMD & $1,822 \mathrm{~cd} \mathrm{~A}$ & $1,601 \mathrm{abc} \mathrm{B}$ & $12.3 \mathrm{~d}$ \\
IMA 2027 & $1,880 \mathrm{~cd} \mathrm{~A}$ & $1,418 \mathrm{bcd} \mathrm{B}$ & $24.5 \mathrm{abcd}$ \\
IMA 5675B2RF & $1,512 \mathrm{ef} \mathrm{A}$ & $984 \mathrm{e} \mathrm{B}$ & $35.2 \mathrm{ab}$ \\
IMA 8276 & $1,671 \mathrm{de} \mathrm{A}$ & $1,352 \mathrm{~cd} \mathrm{~B}$ & $18.5 \mathrm{~cd}$ \\
TMG 42WS & $1,984 \mathrm{bc} \mathrm{A}$ & $1,258 \mathrm{~d} \mathrm{~B}$ & $35.5 \mathrm{a}$ \\
TMG 81WS & $1,966 \mathrm{c} \mathrm{A}$ & $1,662 \mathrm{ab} \mathrm{B}$ & $14.8 \mathrm{~d}$ \\
TMG 82WS & $2,229 \mathrm{ab} \mathrm{A}$ & $1,776 \mathrm{a} \mathrm{B}$ & $20.1 \mathrm{bcd}$ \\
Mean & 1,834 & 1,401 & 23.3 \\
\hline
\end{tabular}

${ }^{x}$ Means within a column followed by the same lowercase letter are not significantly different according to Fisher's protected LSD $(0.05)$. Means within a row followed by the same uppercase letter (comparison of nematicide treated and nontreated plots of each genotype) are not significantly different according to Fisher's protected $\operatorname{LSD}_{(0.05)}$.

${ }^{\mathrm{y}}$ Nematicide treatment was aldicarb at $0.9 \mathrm{~kg}$ a.i./ha in furrow at planting and a side-dress application 30 days after planting.

${ }^{\mathrm{z}}$ Percent yield loss was calculated as [(yield with nematicide/yield without nematicide)/yield with nematicide]*100. 
plots that were not treated (Fig. 2). There was a significant nematicide $\times$ trial interaction $(P=0.0033)$ for the 90 DAP samples, so trials were not combined for analysis. The mean difference of the $R$. reniformis population between plots treated with nematicide and plots that were not treated was $28 \%, 15 \%$, and $40 \%$ for the collection times 60,90 , and 120 DAP, respectively. The effect of the nematicide treatment was similar on all cotton genotypes (no genotype $\times$ nematicide treatment interaction at $60 \mathrm{DAP}$ in Trial $2[P=0.490$ in Trial 1 and $P=0.2190$ in Trial 2] or 90 DAP $[P=0.1010$ in Trial 1 and 0.7640 in Trial 2] or 120 DAP $[P=0.4030$ in Trial 1 and 0.5490 in Trial 2]) with nematode counts being higher in nontreated plots for all genotypes except for IAC 26RMD at 60 DAP in Trial 1.

In Trial 1 (Table 3), nematicide-treated plots averaged $23.9 \%$ greater yield than nontreated plots. The mean yield was $1,728 \mathrm{~kg}$ lint $\mathrm{ha}^{-1}$ for treated plots and $1,315 \mathrm{~kg}$ lint ha $\mathrm{ha}^{-1}$ for plots without nematicide. The genotypes did not all react the same to nematicide application (there was a significant genotype $\times$ treatment interaction; $P=$ 0.0048 ); the yield in treated and nontreated plots of IAC 26RMD did not differ, whereas the other genotypes did differ (Table 3). In Trial 2 (Table 4), the mean difference between the nematicide-treated and nontreated plots was $23.6 \%$, with a mean yield of $1,834 \mathrm{~kg}^{\mathrm{lint}} \mathrm{ha}^{-1}$ in treated plots and $1,401 \mathrm{~kg}$ lint ha $\mathrm{h}^{-1}$ in nontreated plots. In Trial 2, the difference in yield between treated and nontreated plots was statistically significant for all genotypes (Table 4). The pooled analysis of percent yield loss in the two trials revealed significant differences in percent yield loss among genotypes due to $R$. reniformis (Table 5). Percent loss ranged from 10.45 to $34.7 \%$.

Regression analyses. Analysis of the two field trials showed that there was no significant relationship between nematode population levels in the soil and yield loss at 60, 90, or 120 DAP (data not shown). Linear regression plotting the final nematode levels per pot for the 12 cotton genotypes (data from Table 1) against the percent yield loss due to $R$. reniformis (data from Table 5) showed a relationship with $P=0.0854$ and $R^{2}=0.2670$ (Fig. 3A). However, the regression plotting final nematode levels per gram of roots expressed as a percentage of the genotype with the maximum level (calculated from data in Table 1) against percent yield loss found a relationship with $P=0.0095$ and $R^{2}=0.4561$ (Fig. 3B).

The linear regression between the root system size (as measured by root system total length as a percentage of the genotype with the greatest length) and yield in plots treated with nematicide (an attempt to approximate yield potential) did not find a significant relationship $(P=0.3776$; Fig. 4A). Similarly, the relationship was not significant $(P=0.1183)$ for the regression of root system size and yield in plots that were not treated with nematicide (Fig. 4B). The linear regression between root system size and percent yield loss found a relationship with $P=0.0831$ and $R^{2}=0.2704$ (Fig. 5).

Table 5. Percent yield loss of cotton genotypes caused by Rotylenchulus reniformis in 2015

\begin{tabular}{lc}
\hline Genotype & Yield loss $(\boldsymbol{\%})^{\mathbf{y}, \mathbf{z}}$ \\
\hline BRS 371RF & $19.25 \mathrm{~cd}$ \\
BRS 372 & $15.40 \mathrm{~cd}$ \\
DP 555BGRR & $15.50 \mathrm{~cd}$ \\
FM 966LL & $32.10 \mathrm{ab}$ \\
FM 975WS & $34.70 \mathrm{a}$ \\
IAC 26RMD & $10.45 \mathrm{~d}$ \\
IMA 2027 & $22.3 \mathrm{bc}$ \\
IMA 5675B2RF & $43.2 \mathrm{a}$ \\
IMA 8276 & $20.0 \mathrm{~cd}$ \\
TMG 42WS & $35.0 \mathrm{a}$ \\
TMG 81WS & $15.2 \mathrm{~cd}$ \\
TMG 82WS & $17.4 \mathrm{~cd}$ \\
\hline
\end{tabular}

${ }^{y}$ Means within a column followed by the same lowercase letter are not significantly different according to Fisher's protected $\operatorname{LSD}_{(0.05)}$. Pooled analysis of Trials 1 and 2 .

${ }^{\mathrm{z}}$ Percent yield loss was calculated as [(yield with nematicide/yield without nematicide)/yield with nematicide]*100.
Multiple linear regression analysis relating root system size (as measured by root system total length as a percentage of the genotype with the greatest length) and final nematode levels per gram of roots (expressed as a percentage of the genotype with the maximum level) with percent yield loss due to $R$. reniformis was significant. The equation that represented this relationship was as follows: Yield loss $(\%)=16.1258-0.1918 *(\%$ maximum root length $)+0.3728 *(\%$ maximum eggs + vermiform $/ g$ of roots $)\left(P=0.03402\right.$ and $\left.R^{2}=0.5282\right)$.

\section{Discussion}

Plant genotypes may be considered highly resistant if they support less than $10 \%$ of the nematode reproduction supported by susceptible genotypes (Robinson et al. 2004). Although there were differences in the degree of $R$. reniformis reproduction among the cotton genotypes in our study, none were highly resistant. The genotype with the least nematode reproduction had a mean of $49.6 \%$ of the susceptible check. Similar levels of resistance were useful in reducing damage to cotton from Meloidogyne incognita (Davis and May 2005), and the study reported herein found that modest reductions in $R$. reniformis reproduction also reduced yield loss.

In our study, the genotype with the shortest root system was approximately $34 \%$ shorter than the genotype with the longest root system, which is consistent with the range documented in previous studies (Iqbal et al. 2010; Usery et al. 2005). In our study, the mean total root length of the 12 genotypes 48 DAP reached $8,676 \mathrm{~cm}$ for Trial 1 and $9,938 \mathrm{~cm}$ for Trial 2, which is similar to the $6,700 \mathrm{~cm}$ and $4,167.8 \mathrm{~cm}$ lengths reached at 35 DAP in previous studies (Nayakekorala and Taylor 1990; Oosterhuis and Zhao 1994). However, absolute root length data are quite variable and are greatly influenced by growth structure, environment, time, and plant species (James et al. 1985; Judd et al. 2015; Nayakekorala and Taylor 1990); therefore, comparisons among studies can be difficult unless a common genotype is included to facilitate comparisons of data from different experimental environments.

Our study focused on total length of the root system as a variable likely to influence tolerance to $R$. reniformis. Root diameter, root dry weight, root surface area, and length of the taproot were measured in addition to the total root length per plant; however, total root length was the only one of these variables significantly related to percent loss. We did not consider the architectural structure of the root system (Fitter 1987) and aspects such as topology, branching angles, and longevity, which may be other variables to explore for associations with plant tolerance to biotic stresses such as plant-parasitic nematodes. Those variables affect the plant's exploration of the soil and absorption of nutrients and water (especially under conditions where resources are limiting), as well as interactions and competition with soil microorganisms (Fitter et al. 1991; Kiba and Krapp 2016; Paez-Garcia et al. 2015; Postma et al. 2014).

The application of nematicide reduced the population levels of $R$. reniformis even at $120 \mathrm{DAP}$. It is common that nematode population levels where nematicide is applied rebound to levels equal to

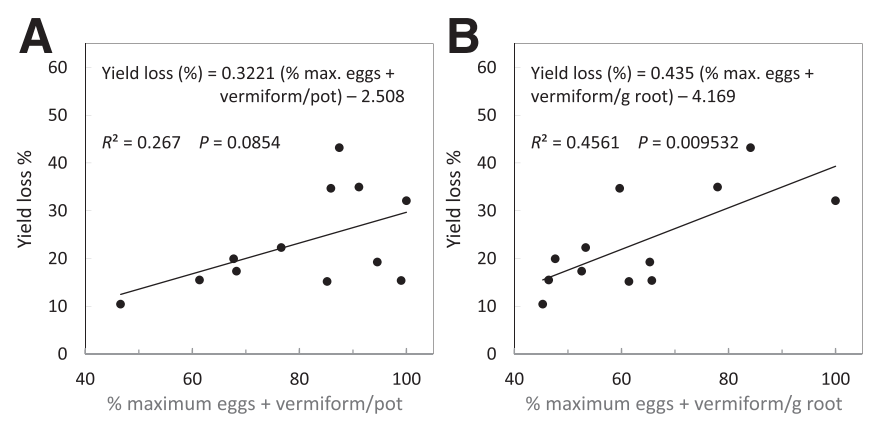

Fig. 3. Linear relationship between $\mathbf{A}$, the mean total nematodes per pot for 12 cotton genotypes (expressed as a percentage of the genotype with the greatest value) and the percent yield loss of those genotypes caused by Rotylenchulus reniformis from field trials, and B, the mean total nematodes per gram of root for 12 cotton genotypes (expressed as a percentage of the genotype with the greatest value) and the percent yield loss of those genotypes caused by $R$. reniformis from field trials. Data were pooled from three reproduction trials in a greenhouse and two field trials in Mato Grosso, Brazil, in 2015. 
nontreated areas later in the growing season (Starr et al. 2007). A relatively high dose of aldicarb plus the split application (at planting and side-dress) (Davis et al. 2003) and favorable environmental conditions likely contributed to the effectiveness of the nematicide treatment in our study. Our results showed that nematode reproduction and subsequent damage to the crop was minimized. The yield loss estimates for our study were obtained by comparing yield in nematode-damaged plots to yield in nematicide-treated plots, which was our best attempt to estimate yield in the absence of nematode damage. Our nematicide-treated plots still had $R$. reniformis present and likely suffered some damage; therefore, actual yield loss caused by $R$. reniformis is likely greater than we were able to measure.

The yield in nematicide-treated plots in our study was $1,728 \mathrm{~kg}$ lint/ha in Trial 1 and 1,834 kg lint/ha in Trial 2. For comparison, yield in nonirrigated fields in the region in which the trials were conducted was $1,638 \mathrm{~kg}$ lint/ha in 2014/15, and the average throughout Brazil was $1,601 \mathrm{~kg}$ lint $/ \mathrm{ha}$ (CONAB 2017). Average yield in plots without nematicide was $1,315 \mathrm{~kg}$ lint/ha for Trial 1 and 1,401 kg lint/ha for Trial 2, which were both lower than the national average. Yield losses in our study ranged from 8.6 to $51.2 \%$ depending on the genotype and the trial. FM 975WS has been the most widely planted cultivar in Brazil in recent years, especially in the state of Mato Grosso where it constituted 60\% of the cotton crop (Galbieri et al. 2016); however, FM 975WS suffered a $34.7 \%$ average loss due to $R$. reniformis in our study. The genotype with the least loss in our study was IAC 26RMD. The cotton breeding program of the Instituto Agronômico de Campinas (IAC) has been developing genotypes in southeastern Brazil with resistance to multiple diseases and nematode tolerance for over 50 years (Cia et al. 2003), but during this time there was no specific attempt to develop resistance to $R$. reniformis. Although IAC 26RMD allowed significant reproduction of $R$. reniformis in our study, the level of reproduction was significantly less than most of the other genotypes. Unfortunately, IAC genotypes typically are not well adapted to the tropical conditions of the Brazilian cerrado found in Mato Grosso, and they lack the insect and herbicide resistance traits desired by many producers.

When the relationships between nematode reproduction and yield loss were evaluated, a stronger relationship was found with nematodes per gram of root rather than with the total numbers of nematodes. The number of nematodes per gram of root can be affected by both the number of nematodes and by amount of root material (size of the root system), and the number of nematodes available to parasitize the roots is greatly affected by the amount of reproduction supported by the cotton genotype. Yield suppression was shown to decease linearly as reproduction of $M$. incognita decreased in moderately resistant cotton; however, a low $R^{2}$ was interpreted to suggest that other factors were contributing to the observed tolerance (Davis and May 2003). A difference in root system size among genotypes appears to be an additional factor contributing to nematode tolerance. Increased root length without an increase in the number of nematodes will result in fewer nematodes per gram of root, which we observed
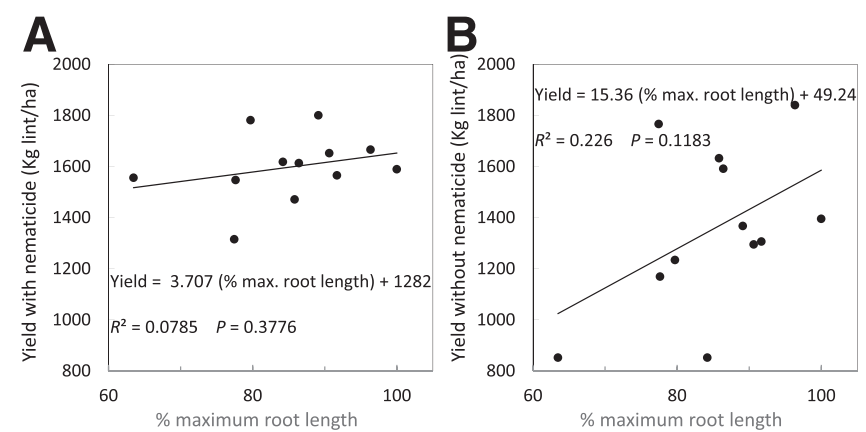

Fig. 4. Linear relationship between $\mathbf{A}$, the mean total root length for 12 cotton genotypes (expressed as a percentage of the genotype with the greatest value) and the mean yield of those genotypes from nematicide-treated plots in field trials, and $\mathbf{B}$, the mean total root length for 12 cotton genotypes (expressed as a percentage of the genotype with the greatest value) and the mean yield of those genotypes from plots without nematicide in field trials. Data were pooled from two root-growth trials in a greenhouse and two field trials in Mato Grosso, Brazil, in 2015. in our study. The number of nematodes per gram of root is a measure of the parasitic load on the plant, and the parasitic load is a direct cause of the losses due to $R$. reniformis in infested fields. Genotypes with fewer nematodes per gram of root were the most tolerant under field conditions in our study.

The root system plays an important role in a plant's ability to cope with both biotic and abiotic stresses (Paez-Garcia et al. 2015). In cotton, genotypes with greater root length were the most tolerant to drought (Zafar and Azhar 2015). Root system length greatly influences the uptake of nutrients for the development of a crop when nutrients are limited (Kiba and Krapp 2016; Rosolem et al. 1999). In our study, the relationship of total root system length with cotton yield was stronger in plots suffering the most damage from $R$. reniformis (not treated with nematicide) than in plots with minimal damage (nematicide treated), which suggests that root system length is a greater asset to the plant when it is under the stress of nematode parasitism.

$R$. reniformis can infect anywhere along the length of the root system (Robinson et al. 1997), and it does not greatly disrupt root growth so that roots continue to grow even when infected by the nematode. Increased parasitism of cotton by $R$. reniformis under greenhouse conditions as measured by the number of eggs produced 60 days after inoculation did not influence measured root parameters (Usery et al. 2005). In contrast, Meloidogyne incognita causes significant disruption of the root system through gall formation (Starr et al. 2007). Therefore, the relationship of root system size to tolerance to $R$. reniformis may be different for other nematodes.

Although genetic resistance may be directly related to a plant's tolerance to a nematode (Cook and Evans 1987; Trudgill 1991), this is not always true. LONREN cotton germplasm lines exhibit resistance to $R$. reniformis but are intolerant to the nematode and exhibit significant yield loss (Schrimsher et al. 2014). Other sources of resistance in cotton to $R$. reniformis with associated molecular markers have been identified (Gutiérrez et al. 2010; McCarty et al. 2012, 2017; Wubben et al. 2017). If genes that govern root length are identified, which is a goal of programs seeking to improve drought tolerance in cotton, associated markers would likely be useful for selecting plants with improved tolerance to $R$. reniformis.

Anything that promotes root system growth may improve tolerance of cotton to $R$. reniformis. Compacted soil decreases cotton root growth (Falkoski Filho et al. 2013) and may consequently increase the parasitic load on the plant, thereby decreasing plant tolerance. According to Galbieri et al. (2016), 20\% of the cotton fields in Mato

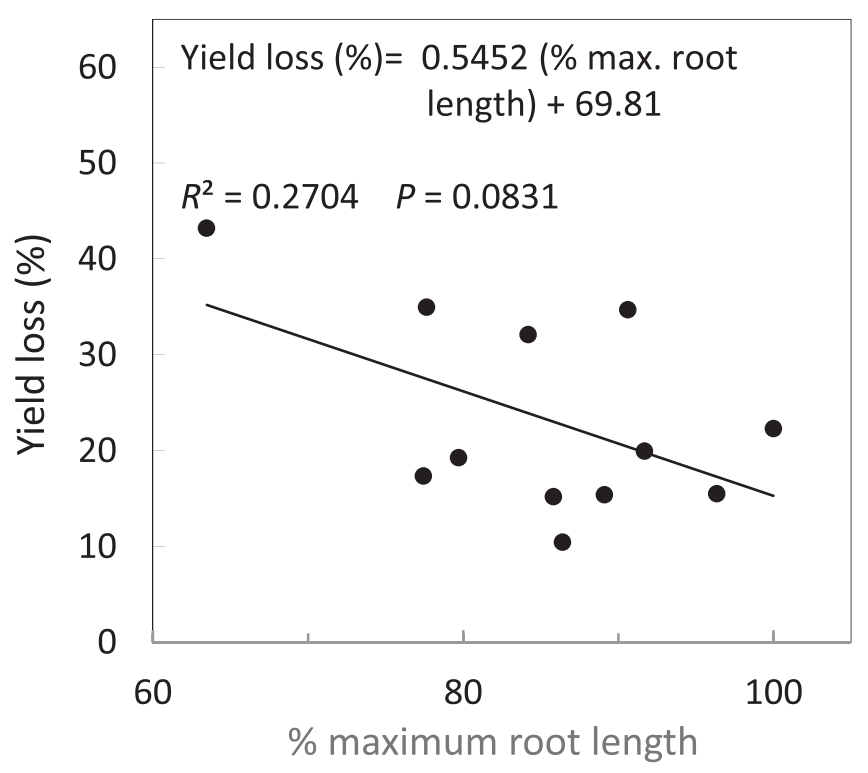

Fig. 5. Linear relationship between the mean total root length for 12 cotton genotypes (expressed as a percentage of the genotype with the greatest value) and the percent yield loss of those genotypes caused by Rotylenchulus reniformis from field trials. Data were pooled from two root-growth trials in a greenhouse and two field trials in Mato Grosso, Brazil, in 2015. 
Grosso have compacted soil. The use of nematicides at the beginning of crop development decreases the amount of nematode infection but also can improve root growth (Robinson et al. 2005), which could be an indirect mechanism of nematicides improving yield. Plant growth regulators, especially in the first weeks of plant development, can increase root length (Oosterhuis and Zhao 1994) and may affect plant tolerance to nematodes. Plant growth promoting rhizobacteria (Tahir et al. 2015) and mycorrhizae (Thompson et al. 2012) also may increase root growth and affect tolerance. Phosphorus and nitrogen fertilization may increase root growth (Postma et al. 2014; Rosolem et al. 1999) and increase the tolerance of cotton to $R$. reniformis. Thinking of the parasitic load on a plant (nematodes per gram of root) as a controlling mechanism of plant tolerance to nematodes helps identify potential avenues for future research.

\section{Acknowledgments}

The authors thank Ketlyn P. S. Freitas and Erisson R. Roberto for their technical assistance.

\section{Literature Cited}

Asmus, G. L., and Ishimi, C. M. 2009. Flutuação populacional de Rotylenchulus reniformis em solo cultivado com algodoeiro. Pesqui. Agropecu. Bras. 44:51-57.

Blessitt, J. A., Stetina, S. R., Wallace, T. P., Smith, P. T., and Sciumbato, G. L. 2012. Cotton (Gossypium hirsutum) cultivars exhibiting tolerance to the reniform nematode (Rotylenchulus reniformis). Int. J. Agron. 2012:1-8.

Cia, E., Fuzatto, M. G., Kondo, J. I., Gridi-Papp, I. L., Chiavegato, E. J., and Pizzinatto, M. A. 2003. Desenvolvimento de resistência múltipla a doenças em linhagens avançadas de algodoeiro. Fitopatol. Bras. 28:420-423.

CONAB. 2017. Safras - grãos safra 2014/2015. Available at: https://www.conab. gov.br/conteudos.php?a=1252\&t. Accessed on June 17, 2017.

Cook, R., and Evans, K. 1987. Resistance and tolerance. Pages 179-231 in: Principles and Practice of Nematode Control in Crops. R. H. Brown and B. R. Kerry, eds. Academic Press, Marrickville, NSW.

Coolen, W. A., and D'Herde, C. J. 1972. A method for the quantitative extraction of nematodes from plant tissue. State Agricultural Research Centre, Ghent., 77 pp.

Davis, R. F., Koenning, S. R., Kemerait, R. C., Cummings, T. D., and Shurley, W. D. 2003. Rotylenchulus reniformis management in cotton with crop rotation. J. Nematol. 35:58-64

Davis, R. F., and May, O. L. 2003. Relationships between tolerance and resistance to Meloidogyne incognita in cotton. J. Nematol. 35:411-416.

Davis, R. F., and May, O. L. 2005. Relationship between yield potential and percentage yield suppression caused by the southern root-knot nematode in cotton. Crop Sci. 45:2312-2317.

Davis, R. F., and Stetina, S. R. 2016. Resistance and tolerance to nematodes in cotton. Pages 166-242 in: Nematoides fitoparasitas do algodoeiro nos cerrados brasileiros: Biologia e medidas de controle. R. Galbieri and J. L. Belot, eds. Instituto Mato-grossense do Algodão - IMAmt, Cuiabá, Brazil.

Falkoski Filho, J., Batista, I., and Rosolem, C. A. 2013. Sensitivity of cotton cultivars to soil compaction. Semin. Cienc. Agrar. 34 (6Supl1):3645-3654.

Fitter, A. H. 1987. An architectural approach to the comparative ecology of plant root systems. New Phytol. 106S:61-77.

Fitter, A. H., Stickland, T. R., and Harvey, M. L. 1991. Architectural analysis of plant root systems 1. Architectural correlates of exploitation efficiency. New Phytol. 118:375-382.

Galbieri, R., Vaz, C. M. P., Asmus, G. L., Crestana, S., Matos, E. S., and Magalhães, C. A. S. 2016. Influência de parâmetros de solo na ocorrência de fitonematoides. Pages 37-89 in: Nematoides fitoparasitas do algodoeiro nos cerrados brasileiros: Biologia e medidas de controle. R. Galbieri and J. L. Belot, eds. Instituto Mato-grossense do Algodão - IMAmt, Cuiabá, Brazil.

Gutiérrez, O. A., Robinson, A. F., Jenkins, J. N., McCarty, J. C., Wubben, M. J., Callahan, F. E., and Nichols, R. L. 2010. Identification of QTL regions and SSR markers associated with resistance to reniform nematode in Gossypium barbadense L. accession GB713. Theor. Appl. Genet. 1:1-10.

Himmelbauer, M. L., Loiskandl, W., and Kastanek, F. 2004. Estimating length, average diameter and surface area of roots using two different image analyses systems. Plant Soil 260:111-120.

Hoagland, D. R., and Arnon, D. I. 1950. Pages 1-32 in: The water culture method for growing plants without soil. California Agricultural Experimental Station Circular No. 347. University of California, Berkeley.

Iqbal, K., Azhar, F. M., Khan, I. A., and Ullah, E. 2010. Assessment of cotton (Gossypium hirsutum) germplasm under water stress conditions. Int. J. Agric. Biol. 12:251-255.

James, B. R., Bartleti, R. J., and Amadon, J. F. 1985. A root observation and sampling chamber (rhizotron) for pot studies. Plant Soil 85:291-293.

Jenkins, W. R. 1964. A rapid centrifugal-flotation technique for separation nematodes from soil. Plant Dis. Rep. 48:692.

Judd, L. A., Jackson, B. E., and Fonteno, W. C. 2015. Advancements in root growth measurement technologies and observation capabilities for containergrown plants. Plants 4:369-392.
Kiba, T., and Krapp, A. 2016. Plant nitrogen acquisition under low availability: Regulation of uptake and root architecture. Plant Cell Physiol. 57:707-714.

Lawrence, K., Hagan, A., Norton, R., Faske, T., Hutmacher, R., Muller, J., Wright, D., Small, I., Kemerait, B., Overstreet, C., Price, P., Lawrence, G., Allen, T., Atwell, S., Jones, A., Thomas, S., Goldberg, N., Boman, R., Goodson, J., Kelly, H., Woodward, J., and Mehl, H. L. 2017. Cotton disease loss estimate committee report, 2016. Pages 150-152 in: Proceeding of the Beltwide Cotton Conference, Dallas, TX, USA, January 4-6.

McCarty, J. C., Jr., Jenkins, J. N., Wubben, M. J., Gutierrez, O. A., Hayes, R. W., Callahan, F. E., and Deng, D. 2012. Registration of three germplasm lines of cotton derived from Gossypium barbadense L. accession GB713 with resistance to the reniform nematode. J. Plant Regist. 7:220-223.

McCarty, J. C., Jr., Jenkins, J. N., Wubben, M. J., Hayes, R. W., Callahan, F. E., and Deng, D. 2017. Registration of six germplasm lines of cotton with resistance to the root-knot and reniform nematodes. J. Plant Regist. 11:168-171.

McMichael, B. L., and Quisenberry, J. E. 1991. Genetic variation for root-shoot relationships among cotton germplasm. Environ. Exp. Bot. 31:461-470.

Mills, N. B., Oosterhuis, D. M., and McMichael, B. L. 2012. Seedling root growth response to cool environmental conditions for diverse cotton cultivars. Am. J. Exp. Agric. 2:269-287

Nayakekorala, H., and Taylor, H. M. 1990. Phosphorus uptake rates of cotton roots at different growth stages from different soil layers. Plant Soil 122:105-110.

Oosterhuis, D. M., and Zhao, D. 1994. Increase root length and branching in cotton by soil application of the plant growth regulator PGR-IV. Plant Soil 167:51-56

Paez-Garcia, A., Motes, C. M., Scheible, W., Chen, R., Blancaflor, E. B., and Monteros, M. J. 2015. Root traits and phenotyping strategies for plant improvement. Plants 4:334-355.

Postma, J. A., Schurr, U., and Fiorani, F. 2014. Dynamic root growth and architecture responses to limiting nutrient availability: Linking physiological models and experimentation. Biotechnol. Adv. 32:53-65.

Quisenberry, J. E., and McMichael, B. L. 1996. Screening cotton germplasm for root growth potential. Environ. Exp. Bot. 36:333-337.

R Development Core Team. 2014. R: A Language and Environment for Statistical Computing. R Foundation for Statistical Computing, Vienna.

Robinson, A. F. 2007. Reniform in U.S. cotton: When, where, why, and some remedies. Annu. Rev. Phytopathol. 45:263-288.

Robinson, A. F., Bridges, A. C., and Percival, A. E. 2004. New sources of resistance to the reniform (Rotylenchulus reniformis Linford and Oliveira) and root-knot (Meloidogyne incognita (Kofoid \& White) Chitwood) nematode in upland (Gossypium hirsutum) L.) and Sea Island (G. barbadense L.) cotton. J. Cotton Sci. 8:191-197.

Robinson, A. F., Cook, C. G., Westphal, A., and Bradford, J. M. 2005. Rotylenchulus reniformis below plow depth suppresses cotton yield and root growth. J. Nematol. 37:285-291.

Robinson, A. F., Inserra, R. N., Caswell-Chen, E. P., Vovlas, N., and Troccoli, A 1997. Rotylenchulus species: Identification, distribution, host ranges, and crop plant resistance. Nematropica 27:127-180.

Rosolem, C. A., Witacker, J. P. T., Vanzolini, S., and Ramos, V. J. 1999. The significance of root growth on cotton nutrition in an acidic low- $P$ soil. Plant Soil 212:183-188

Schrimsher, D. W., Lawrence, K. S., Sikkens, R. B., and Weaver, D. B. 2014 Nematicides enhance growth and yield of Rotylenchulus reniformis resistant cotton genotypes. J. Nematol. 46:365-375.

Sharma, S. B., and Ashokkumar, P. 1991. A screening technique to evaluate pigeonpea for resistance to Rotylenchulus reniformis. Ann. Appl. Biol. 119:323-330.

Starr, J. L., Koenning, S. R., Kirkpatrick, T. L., Robinson, A. F., Roberts, P. A., and Nichols, R. L. 2007. The future of nematode management in cotton. J. Nematol. 39:283-294

Tahir, M., Mirza, M. S., Hameed, S., Dimitrov, M. R., and Smidt, H. 2015. Cultivation-based and molecular assessment of bacterial diversity in the rhizosheath wheat under different crop rotations. PLoS One 10:e130030.

Thompson, J. P., Seymour, N. P., and Clewett, T. G. 2012. Stunted cotton (Gossypium hirsutum L.) fully recovers biomass and yield of seed cotton after delayed root inoculation with spores of an arbuscular mycorrhizal fungus (Glomus mosseae). Australas. Plant Pathol. 41:431-437.

Trudgill, D. L. 1991. Resistance to and tolerance of plants parasitic nematodes in plants. Annu. Rev. Phytopathol. 29:167-192.

USDA-FAS. 2017. Production, supply and distribution online. USDA-FAS Washington, DC. https://apps.fas.usda.gov/psdonline/app/index.html\#/app/ advQuery (accessed July 2017).

Usery, S. R., Jr., Lawrence, K. S., Lawrence, G. W., and Burmester, C. H. 2005. Evaluation of cotton cultivars for resistance and tolerance to Rotylenchulus reniformis. Nematropica 35:121-133.

Walters, S. A., and Barker, R. 1993. Comparison of two inoculum preparation methods for Rotylenchulus reniformis. J. Nematol. 25S:778-784.

Weaver, D. B. 2015. Cotton nematodes. Pages 1-24 in: Cotton. D. D. Fang and R. G. Percy, eds. ASA, CSSA and SSSA, Madison, WI.

Wubben, M. J., McCarty, J. C., Jr., Jenkins, J. N., Callahan, F. E., and Deng, D. D. 2017 Individual and combined contributions of the Ren ${ }^{\text {barb1 }}$, Ren $^{\text {barb2 } 2}$, and Ren ${ }^{\text {barb3 }}$ quantitative trait loci to reniform nematode (Rotylenchulus reniformis Linford \& Oliveira) resistance in upland cotton (Gossypium hirsutum L.). Euphytica 213:47.

Zafar, S., and Azhar, M. T. 2015. Assessment of variability for drought tolerance in Gossypium hirsutum L. at seedling stage. Pak. J. Agric. Sci. 52:301-307. 